Jerzy Ostapczuk (Warsaw)

\title{
Typological Classification of the Cyrillic Manuscripts and EArly Printed Books WITH THE GOSPEL TEXTS
}

$\mathrm{T}$ The tradition of dividing the books of the Holy Scripture is very old. It was known already in the Jewish tradition, in which the biblical texts received a threefold division: 1) the Law or the Pentateuch (Torah), 2) the Prophets (Nebi'im), and 3 ) the Writings (Ketuvim) ${ }^{1}$. This tripartite canon was recognized by the authors of the New Testament (Luke 24,44; John 10,35; 2 Tm 3,15), as well.

The Evangelists and Apostles (2 Cor 3,14; Heb 8,7 etc.) distinguished in the Holy Scripture the $\mathrm{Old}^{2}$ and the New Testament. This division was established by the Church Fathers (e.g. Origens), who divided the second part of the Bible into the

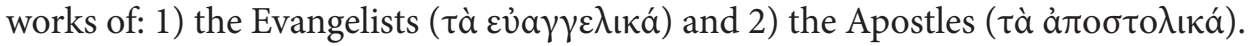
These ancient divisions of the Holy Scripture served as a model for any further divisions with regard of the characteristic features and aspects of the books (i.e. their authorship, the date of creation or the type of the text).

The Gospels, written in the $1^{\text {st }}$ century in the Greek language, are an inseparable component of the Bible, especially of its second part - the New Testament. This, however, does not mean that they always had stand a part of the Bible or the New Testament, for they could have been written in one separate and independent codex together with the Acts and Epistles of the Holy Apostles (i.e. Apostolos), but without the Apocalypse (Revelation). The Gospels, similarly to the Apostolos, could have also constituted a separate volume. This is why the Greek tradition of the Holy Scripture of the New Testament distinguished several different types of the books with Gospel text, namely: the Bible, the New Testament, the Gospels with the Apostolos ${ }^{3}$ and finally only the Gospels.

The Sacred tradition regarded only four Gospels as canonical, i.e. those written by Matthew, Mark, Luke, and John. The text of these four books - written

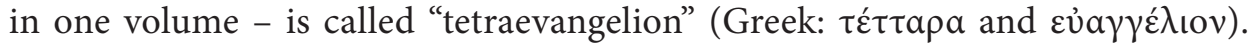

\footnotetext{
${ }^{1}$ The Tanakh is the acronym of the Hebrew Bible's tripartite division.

${ }^{2}$ In the Jewish tradition, the Old Testament was divided into: 1) historical books (21 books), 2) didactical ( 7 books), and 3$)$ prophetical (16 books). Similarly the New Testament, which was divided into: historical (4 Gospels), didactical (Acts and Epistles of Holy Apostles) and prophetical (Revelation). ${ }^{3}$ The Apocalypse is the only New Testament book excluded from public reading at Orthodox services.
} 
The development of the liturgical tradition and various regularities of celebration of Divine Liturgies - in rural areas, cathedral and metropolitan cities or monasteries - resulted in the division of the Gospel text into liturgical readings (pericopes) and the extension of the tetragospels with a supplement containing essential information for priests about the order in which the pericopes occur in the church year. The products of these liturgical needs were tetraevangelions with different divisions of the Gospel texts - corresponding to the frequency of celebrating Divine Liturgies - and a liturgical apparatus placed at the end of the volume or sometimes - when divided into two parts: the Synaxarion ${ }^{4}$ and the Menologion ${ }^{5}$ - also at its beginning.

Most of the liturgical readings comprise of only of a single fragment from a Gospel, but some of them may include several fragments, i.e. two ${ }^{6}$, three ${ }^{7}$ or even five $^{8}$, taken from one or even different Gospel books. A good example of the latter is the periscope for the Good Friday Vespers, which reading contains five fragments from three Gospels: of Matthew (27,1-38), of Luke (23,39-43), of Matthew $(27,39-54)$, of John $(19,31-37)$ and once again of $(27,55-61)$.

The system of liturgical readings was in some cases quite complicated, as some pericopes incorporated fragments from different parts of the tetraevangelion. In case of the above-mentioned pericope, priests had to read first the fragment from the first Gospel book (Matthew), then from the third (Luke), and again from the first (Matthew), from the last (John) and again from the first (Matthew). This problem with looking for the appropriate Gospel fragments by a priest did not occur (at least not entirely) in relation to the other type of the book with the text of the Gospel, i.e. the lectionary, in which the Gospel text divided into pericopes is arranged according to the cycles of the church year and is chanted in this order by

\footnotetext{
${ }^{4}$ The Synaxarion (the so-called "moveable year") begins with Easter and provides readings for the moveable feast days.

${ }^{5}$ The menologion (the so-called "fixed year") begins on September 1 (the Indiction, i.e. the beginning of the secular year) and contains readings for fixed feast days.

${ }^{6}$ For example readings for: the Holy Pentecost: John 7,37-51 and 8,12; the $16^{\text {th }}$ Saturday of Matthew: Matt 24,34-49 and 42-44.

${ }^{7}$ For example readings for: the $1^{\text {st }}$ Sunday of Matthew: Matt $10,32-33.37-38$ and $19,27-30$; the $17^{\text {th }}$ Friday of Luke: Mark 15,22.25.33-41. It is worth mentioning that the last reading from the Gospel of Mark 15,22.25.33-41 (with omission of the verses 23-24 and 26-32) corresponds to the results of the historical-critical method of research carried out by Wolfgang Schenk (W. ScHENK, Die gnostisierende Deutung des Todes Jesu und ihre kritische Interpretation durch den Evangelisten Markus, [in:] Gnosis und Neues Testament: Studien aus Religionswissenschaft und Theologie, ed. K.-W. TröGER, Berlin 1973, p. 231-243). In his opinion, the Gospel of Mark at 15,22-41 contains doublets and additions. This part of the text has also two separate descriptions of the crucifixion. The similarity of the Gospel reading to the reconstruction of the primary Gospel text, carried out by W. Schenk, shows that the Orthodox system of liturgical readings could have been created even in the $1^{\text {st }}$ century, even before the edition of the New Testament's text.

${ }^{8}$ For example readings for the Elevation of the Holy Cross: John 19,6.9-11.13-20.25-28.30-35.
} 
the priests during the Divine Liturgies throughout the entire year, i.e. the pericope for Monday, the pericope for Tuesday, the pericope for Wednesday etc. On the basis of the different number of Scripture readings at the Synaxarion ${ }^{9}$ the typological classification of the lectionaries was carried out.

A distinction of the various types of books containing the Gospel text was already characteristic for Greek tradition. It was based on some principles: the arrangement of the text in the Gospel or the liturgical pericopes and various regularities of celebrating Divine Liturgies - in rural areas, cathedral and metropolitan cities or monasteries. This classification was not based on the characteristics of the Gospel text (i.e. textual variants), as this is the basis for textological classification ${ }^{10}$.

In the catalogue of the Greek manuscripts of the New Testament published by Kurt Aland, two ${ }^{11}$ main types of books with the Gospel text have been distinguished with the following abbreviations ${ }^{12}$ :

- e - tetraevangelions;

$-l$ - Gospel ${ }^{13}$ lectionaries ${ }^{14}$.

${ }^{9}$ The number of the Gospel readings at the menologion was not taken into account during the typological classification of the lectionaries.

${ }^{10}$ Authors of the Chicago Lectionary Project examined the text of the Gospel lectionaries. For the results of the Project (with main publications (including doctoral dissertations) of H.M. Buck, W.F. Specht, R. Harms, B.M. Metzger, W.D. Bray, J.R. Branton, F.C. Kuehner, D. Pellett, M.W. Redus and A.S. Illingworth) see: A. Wikgren, Chicago studies in the Greek Lectionary of the New Testament, [in:] Biblical and Patristic Studies in Memory of Robert Pierce Casey, ed. J.N. Birdsall, R.W. Thomson, Freiburg 1963, p. 96-121; M.L. Dolezal, The Elusive Quest for the „Real Thing”: The Chicago Lectionary Project Thirty Years On, Ges 35/2, 1996, p. 128-141; А.А. Алексевв, Библия в богослужении. Византийско-славянский текиионарий, Санкт-Петербург 2008, p. 109-113; J. Ostapczuк, Cerkiewnosłowiański przekład liturgicznych perykop okresu Paschalnego i święta Pięćdziesiątnicy w rękopiśmiennych ewangeliarzach krótkich, Warszawa 2010, p. 146-157.

${ }^{11}$ See also A.M. Пентковский, Лекционарии и четвероевангелия в византийской и славянской литургических традициях (Приложение 1), [in:] Евангелие от Иоанна в славянской традиици (Novum Testamentum Palaeoslovenice I), ed. А.А. АлЕКСеЕв, А.А. ПичХАДЗЕ, М.Б. БАБИЦКАЯ et al., Санкт-Петербург 1998, p. 1.

${ }^{12}$ K. Aland, Kurzgefasste liste der griechischen Handschriften des Neuen Testaments: I Gesamtübersicht (Arbeiten zur Neutestamentlichen Textforschung 1), Berlin 1963, p. 23-24. See also: K. Aland, B. Aland, The Text of the New Testament. An Introduction to the Critical Editions and to the Theory and Practice of Modern Textual Criticism. Second Edition, trans. by E.F. Rhodes, Grand Rapids Michigan 1989, p. 170; А.М. Пентковский, op. cit., p. 4.

${ }^{13}$ The abbreviation $l^{a}$ was used for lectionaries with the text of the Apostolos (K. Aland, op. cit., p. 24), i.e. the Acts and Epistles of the Holy Apostles. It is also sometimes called "The Epistle Lectionary" (The Epistle Lectionary. The Apostolos of the Greek Orthodox Church According to the King James Version. Emended and Arranged for the Liturgical Year, Etna (California) 2004). The lectionary of the Old Testament is called "prophetologion" (see A.А. Алексевв, Византийско-славянский профитологий (формирование состава), ТОДЛ, LVI, 2004, p. 46-77; А.А. АлексеЕв, Библия в богослужении..., p. 159-193).

${ }^{14}$ This symbol is used for the lectionary with Byzantine Church order. There are also others, for example the Palestine lectionary (А.А. АлЕксевв, op. cit., p. 12-15; А.М. ПЕнтковский, op. cit., p. 10). 
Also, the manuscripts called the Apostolos-Gospel lectionary $\left(l^{+a}\right)$ were distinguished, which contain readings from the Gospel and the Apostolos.

Beside theses, there were also other sigla for Acts and Catholic Letters (a), Pauline Letters (p) and Revelation (r). These abbreviations were used in those cases, in which the manuscript comprised of more than one group of the books of the New Testament. An example of such type of manuscript can be the Codex Sinaiticus, which has the following abbreviation: eapr ${ }^{15}$.

Kurt Aland did not divide the tetraevangelia into subgroups ${ }^{16}$, as he did with the lectionaries, among which he distinguished ${ }^{17}$ :

- le - a lectionary with liturgical pericopes for all days of the week ${ }^{18}$ in the

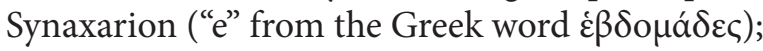

- lesk - a lectionary with pericopes for all days of the week from Easter to

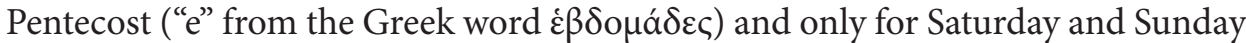

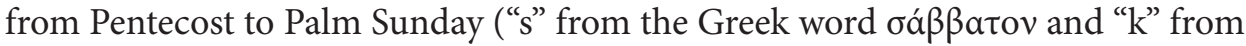
the Greek word кupıакท́);

- lsk - a lectionary with pericopes only (with some exceptions ${ }^{19}$ ) for Saturday and Sunday ("s" from the Greek word oá $\beta \beta \alpha \tau o v$ and "k" from the Greek word кvрıкń);

- lsel - a lectionary with pericopes for the Great Feasts ${ }^{20}$ of the Church ("sel" from the Latin word selectio);

- lLit - a lectionary which, except for the fragments from the New Testament, comprises predominantly of liturgical texts ${ }^{21}$, for example three different Divine Liturgies and for different occasions (Baptism, Confirmation, Funeral, etc.).

The presented above typological classification developed from continuous research on the Greek biblical manuscripts. Among the lectionaries appears also another type with the abbreviation $l k$ and it contains pericopes only (with some

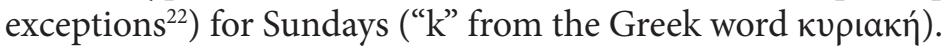

\footnotetext{
${ }^{15}$ K. Aland, op. cit., p. 37.

${ }^{16}$ Among Greek tetraevangelia there are those with partial liturgical division of the Gospel text into pericopes - corresponding to the lesk type lectionary - as well as those with full division of the Gospel text into pericopes - corresponding to the le type lectionary (А.М. Пентковский, op. cit., p. 7). ${ }^{17}$ K. Aland, op. cit., p. 24; K. Aland, B. Aland, op. cit., p. 170. See also A.A. Алексеев, op. cit., p. 29-30. ${ }^{18}$ This doesn't apply to the movable feast days when the liturgy, according to Typicon, is not celebrated, for example: Monday to Friday during Lent.

${ }^{19}$ For example Holy Thursday and Good Friday of the Holy Week, Monday and Tuesday after the Easter. ${ }^{20}$ The Greek Gospel lectionary (1300) preserved at the Library of St. Catherine monastery on Sinai (no 204; 1000 y.; 204 folios) comprises only of 71 Gospel fragments. Another lectionary (l1044) of this type (lsel) preserved at the University Library in Iaşi (no 194; end of the $8^{\text {th }}$ - beginning of the $9^{\text {th }}$ c.) has only 18 Gospel fragments. See J. Ostapczuk, op. cit., p. 34.

${ }^{21}$ The liturgical manuscripts (for example euchologias or Prayer books) even with a few New Testaments pericopes are usually classified to this group of the lectionaries.

${ }^{22}$ For example Holy Thursday and Good Friday of the Holy Week, Monday and Tuesday after the Easter.
} 
This typological classification, developed for the Greek manuscripts ${ }^{23}$, schol$\operatorname{ars}^{24}$ adopted for the Slavic tradition - treated as its younger equivalent. In most cases, both Greek and Slavonic ${ }^{25}$ books exploit the same types of Gospel manuscripts. But in the last one there are some types of Gospel manuscripts not known in the first one ${ }^{26}$. This typological classification of the Gospel manuscripts was adopted also for the Cyrillic early printed books (to the year 1800).

Church Slavonic tetraevangelions were divided into three types. This classification was not done on the basis of the order of the four Gospels (Matthew, Mark, Luke and John), but on the liturgical information located on margins or introduced into the Gospel text. These information and liturgical apparatus placed at the end of the codex enabled tetraevangelia to be used for Divine Liturgies in rural areas, cities or monasteries. These three types $\mathrm{are}^{27}$ :

- tetraevangelia without or with partial liturgical instructions (usually on margins) and the division of the Gospel text into pericopes;

- tetraevangelia with full liturgical instructions (usually within the body of the text) and the division of the Gospel text into pericopes;

- tetraevangelia with full liturgical instructions and the division of the Gospel text into pericopes for reading only during weekdays (from Monday to Friday) of the Lent.

The first group of the tetraevangelia is sometimes divided by some scholars, e.g. by J. Vrana ${ }^{28}$, into two separate groups, i.e.: 1) those without instructions and the division of the Gospel text into pericopes; 2) those with instructions and the division of the Gospel text into pericopes with a liturgical apparatus at the end (or at the beginning) of the manuscript.

${ }^{23}$ Codices of the New Testament didn't have the abbreviation eapr, but NT (M. Garzaniti, Die altslavische Version der Evangelien: Forschungsgeschichte und zeitgenössische Forschung [BSPK.SF 33], Köln-Weimar-Wien 2001, p. 527). In the history of biblical studies, the abbreviation systems of the biblical manuscripts were developed several times. For example Herman von Soden described codices of the New Testament with the letter $\delta$ (from Greek word $\delta\llcorner a \theta \eta \dot{\kappa \eta}$ ).

${ }^{24}$ For example G.A. Voskresenski, L.P. Zhukovskaia, E. Dogramadzieva, L. Moszyński, A.A. Alekseev, M. Garzaniti, S.J. Temčin, etc.

${ }^{25}$ Marcello Garzaniti, in his hugely influential book on the Slavonic Gospel, used also the abbreviations: brev., miss. and lec. (M. Garzaniti, op. cit., p. 510-511), as in his list of manuscripts he included also missals and breviars.

${ }^{26}$ This opinion is true till the moment the same types of the Gospels (e.g. lectionaries) are discovered in the Greek tradition.

${ }^{27}$ For more on this types of the Gospels (with cited literature) see J. Ostapczuk, op. cit., p. 105-148.

${ }^{28} \mathrm{~J}$. VRAna, O tipovima, redakcijama i međusobnom odnosu staroslovjenskih evandelija (Četveroevandelja), Sla XXIX.4, 1960, p. 552-553. 
Most of the catalogued Slavonic tetraevangelia manuscripts belong to the first two groups ${ }^{29}$. Only three ${ }^{30}$ manuscripts, written at the territories of Pskov ${ }^{31}$ and dated to the second half of the $14^{\text {th }}$ century, belong to the third group.

The comparison of both Greek and Slavonic tetraevangelia manuscript tradition showed that in the first one the Lenten tetraevangelion is not known. This type of the Gospel manuscript was popular only in the Slavonic tradition, but only locally and in the second half of the $14^{\text {th }}$ century.

The text of the four Gospels, in the commonly accepted order, could have been a part of the other books, i.e. the New Testament or the Bible.

On the basis of preserved Slavonic manuscripts it can be stated that those volumes which were a combination of the Tetraevangelion and the Apostolos in one volume were not popular in Slavonic tradition. Only several codices of this type have survived to this day and they are usually ${ }^{32}$ dated to the $15^{\text {th } 33}, 16^{\text {th }} 34,17^{\text {th } 35}$, or even the $18^{\text {th }} 36$ century.

Such combination of the tetraevangelion with the Apostolos and the Revelation in one volume - as in the previous case $(\mathrm{e}+\mathrm{a})$ - was also not popular in Slavonic

${ }^{29}$ The oldest manuscripts belong to the first group of tetraevangelia (J. OsTAPCZUK, op. cit., p. 105). The number of pericopes corresponds to abbreviated (lesk) lectionaries (see L. MoszyŃski, Zografskie i Mariańskie Tetraewangelia jako księgi liturgiczne. Część I: Etap głagolski, ПК XIV-XV, 1985, p. 76-99; А.М. Пентковский, ор. cit., p. 15). In time the number of pericopes were extended to correspond to the full lectionaries (J. OstapczuK, op. cit., p. 107). The second group - liturgical tetraevangelia - belong to younger manuscripts (J. OstAPCZUK, op. cit., p. 106). The number of pericopes in these codices corresponds to the full (le) lectionaries (see L. MoszyńsKi, op. cit., p. 76-99; A.M. Пентковский, op. cit., p. 15).

${ }^{30}$ Two of them are preserved at the Russian State Archive of Ancient Acts at Synodal Collection (ф. 381) № 1 (about 1341 y.; 152 folios) and № 3 (mid. XIV c., 144 folios); the third one at the National Library of Russia in St. Petersburg at Collection of Library of the Cathedral of St. Sophia in Novgorod (ф. 728) № 9 (end XIV c.; 136 folios).

${ }^{31}$ Sее Сводный каталог славяно-русских рукописных книг, хранящихся в России, странах СНГ и Балтии, ХІV век, fasc. 1 (Апокалипсис - Летопись Лаврентьевская), еd. О.А. КнязЕвскАЯ, Н.А. КоБяк, А.Л. ЛиФшиц, Н.Б. Тихомиров, А.А. Турилов, Н.Б. ШелАмАновА, Москва 2002, p. 381-382, 410, 461.

${ }^{32}$ For example the manuscript preserved at the Bulgarian National Library Sts. Cyril and Methodius in Sofia № 509 (mid. of the $14^{\text {th }}$ c.; 215 folios).

${ }^{33}$ For example the manuscripts preserved at: the National Library of Russia in St. Petersburg at Pogodin’s Collection № 106 (IV quart. of the $15^{\text {th }}$ c.; 329 folios); Russian State Library in Moscow at Rumiantsev's Collection ( $\phi .256)$ № 123 (II half of the $15^{\text {th }}$ c.; 469 folios) and Egorov's Collection (ф. 90) no 2070 (1540/1541 y.); National Library of France № Slav 27 (mid. $15^{\text {th }}$ c.; 298 folios).

${ }^{34}$ For example the manuscript preserved at: the National Library of Russia in St. Petersburg № F.I.657 (end of the $15^{\text {th }}$ - beginning of the $16^{\text {th }}$ c.; 331 folios).

${ }^{35}$ For example the manuscript from the Russian State Library in Moscow № M.3881 (17 ${ }^{\text {th }}$ c.; 298 folios).

${ }^{36}$ For example the manuscript from the Treasure of the Institute of Russian Literature (The Pushkin House) in St. Petersburg at I.N. Zavoloko’s Collection № 335 (I quart. of the $18^{\text {th }}$ c.; 540 folios). 
tradition. Only a few codices of this type, i.e. the New Testament ${ }^{37}$, sometimes with the addition of the book of Psalms ${ }^{38}$, were preserved to this day.

The compilation of all books of the Holy Scripture, i.e. the Old and New Testament in one volume, which makes for the complete codex of the Bible, was with high probability a huge challenge due to a number of reasons (translation ${ }^{39}$, philological edition ${ }^{40}$, finances). This type of book in the Slavonic tradition was produced for the first time in the 1499 at the end of the $15^{\text {th }}$ century. This was the Gennady's Bible and was the result of the venture of Gennady, archbishop of Novgorod the Great and Pskov.

In the Slavonic tradition, apart from those books with the text of the four Gospels in a commonly accepted order, there were also books containing Gospel readings arranged according to the cycle of the church year. Such type of manuscript is known as the aprakos.

The Slavonic manuscripts of the gospel lectionaries - as in the Greek tradition - can be divided into the following groups ${ }^{41}$ :

- le - the so-called full lectionaries;

- lesk - the so-called abbreviated lectionaries;

- lsk - the so-called Saturday-Sunday lectionaries;

- lk - the so-called Sunday lectionaries;

- lek - the so-called Easter-Sunday lectionary ${ }^{42}$.

In the Slavonic tradition, as in the Greek known were also liturgical books containing a complex array of texts, because beside fragments from the New Testament, they also comprise the liturgical services (i.e. Divine Liturgies, sacraments, etc.). These books have usually the abbreviation lLit. Within this group of lectionaries, called sometimes euchological ${ }^{43}$, S.J. Temčin distinguished the so-called columnar

\footnotetext{
${ }^{37}$ For example: the lost Chudov New Testament of metropolitan Aleksii of Kyiv and all Rus; the manuscript from the Treasure of the Institute of Russian Literature (The Pushkin House) in St. Petersburg at Karelia's Collection № $478\left(16^{\text {th }}\right.$ c., 332 folios); the manuscript from the National Library of St. Mark’s in Venice № Or 227 ( $14^{\text {th }}$ c.; $1+289$ folios).

${ }^{38}$ For example the Codex of Hval Krstjanin from the University Library in Bologna № 3575B (1404 y., 359 folios).

${ }^{39}$ Because not all books (if concerns the Old Testament) were translated.

${ }^{40}$ Books were translated in different places and in different centuries.

${ }^{41}$ For more on these types of the Gospels lectionaries (with cited literature) see J. OsTAPCZuk, op. cit., p. 36-83.

${ }^{42}$ Only one manuscript of this type is known - it is preserved at the Archive of the Bulgarian Academy of Science in Sofia № 49 ( $16^{\text {th }}$ c., 285 folios ( $l^{+ \text {a }}$ : ff. 50-285)). The first information about the typology of this lectionary was published by S.J. Temс̌in (С.Ю. Темчин, Пасхально-воскресный апракос - неизвестный структурньй тип славянского служебного Евангелия, УЗРПУ, fasc. 4, Москва 1998, p. 61-79).

${ }^{43}$ Seе: А.А. Турилов, Л.В. МошковА, Славянские рукописи Абонских обителей, Фессалоники 1999, р. 44-45; С.Ю. ТЕмчин, О возможном балканском влиянии на структуру церковнославянских богослужебных книг ВКЛ и Польского Королества, SRu XVIII, Budapest 2000, p. 278.
} 
lectionary ${ }^{44}$. Its most characteristic feature is that it does not ${ }^{45}$ have two liturgical parts corresponding to the Synaxarion and the Menologion, but has at least two $^{46}$ sets of the New Testament readings. These fragments are read during the ecclesiastical year or one of its cycles ${ }^{47}$ once, several or many times. The other lectionaries of type $l$ Lit, which have a small number of the New Testament readings - can be called the Apostolos-Gospel readings ${ }^{48}$. It is worth mentioning here, two reconstructed (by S.J. Temčin) aprakoses ${ }^{49}$ : the Easter lectionary and the Slavonic protolectionary. A parallel examination of the Greek liturgical books will probably prove the existence in Greek tradition of similar subgroups to the Slavonic types of the lectionaries (columnar and Easter). Too little research has been carried out on these types of the Gospel books. At the moment, more questions remain than answers about these Greek and Slavonic lectionaries. For this reason it is such an important challenge, that scholars should not ignore these books and pay serious attention to this fundamental question. Every new information about these liturgical books will lead to further progress.

The comparison of the distinguished types of the lectionaries both in the Slavonic and Greek traditions showed that the former tradition comprised of no known aprakos $l$ sel $^{50}$ whereas the latter of the Easter-Sunday lectionary (lek).

The changes the Slavonic Gospel manuscript tradition underwent in a period of decades left their trace on the Cyrillic printed tradition. There is no doubt that the latter is an heir of the former ${ }^{51}$.

\footnotetext{
${ }^{44}$ More on this type of the Gospel (with cited literature) see J. Ostapczuk, op. cit., p. 95-103 and the updated publication of S.J. Temс̌in: С.Ю. Темчин, Исследования по кирилло-мефбодиевистике и палеоставистике [KWSS 5], Kraków 2010, p. 147-202.

${ }^{45}$ In columnar lectionaries there are not liturgical cycles (С.Ю. Темчин, Столпный апракос-ещце один неизвестный структурный тип славянского служебного Евангелия (по рукописям XIIIXVI веков), [in:] Библия в духовной жизни, истории и культуре России и православного славянского мира: К 500-летию Геннадиевской Библии, Сборник материалов международной конферениии (Москва, 21-26 сентября 1999 г.), ед. Г. БАРАнковА, Москва 2001, р. 128; С.Ю. Темчин, Сербский столпный апракос Равулы (ок. 1353 г.): происхождение, особенности языка, структура, SVi 52.2), 2003, p. 132; С.Ю. ТЕмчин, Исследования по кирилло-мефодиевистике..., ор. cit., p. 148.

${ }^{46}$ Four blocks of the New Testaments readings have been distinguished (J. OstapczuK, op. cit., p. 96; С.Ю. Темчин, op. cit., p. 148).

${ }^{47}$ С.Ю. Темчин, Столиньй апракос..., p. 127-128.139.

${ }^{48}$ They are simply selections from the Gospel, the Acts and Epistles and do not make a permanent liturgical structure (С.Ю. Темчин, op. cit., p. 158).

${ }^{49}$ For more on these types of the Gospels lectionaries (with cited there literature) see J. OstAPCzUK, op. cit., p. 83-95.

${ }^{50}$ А.М. ПЕнтковский, op. cit., p. 14.

${ }^{51}$ We also have to remember about the influence of the early printed books on the manuscripts (A. KASZLEJ, Wpływ cerkiewnosłowiańskiej książki drukowanej na rękopiśmienna (na podstawie zbiorów Biblioteki Narodowej w Warszawie), [in:] Najstarsze druki cerkiewnosłowiańskie i ich stosunek
} 
Tetraevangelia without or with a partial liturgical division of the Gospel text into pericopes, that were popular in the oldest period of the Slavonic writing tradition, were in time replaced with liturgical tetraevangelia. Their origin is usually connected with the reforms of Saint Sava of Serbia (1169-1237) ${ }^{52}$. Among early printed Gospel books there are not known the first and the third (known only on a local scale) types of the Slavonic tetraevangelion. The only known type of the early printed Gospels is the liturgical tetraevangelion. It was first ${ }^{53}$ published in 1512 by the hieromonk Makarie in Tîrgovişte. Till the year 1800, this type of the Gospel was printed about 120 times $^{54}$.

Among the Cyrillic early printed books none are known that were originally intended by the printer to be the combination of the Tetraevangelion and the Apostolos. It was possible to join these two separately printed books in one volume with their own title pages. This type of book can be treated as codex e+a.

The text of the four Gospels, in a commonly accepted order, could have been included also in other early printed books. Two of them are ${ }^{55}$ :

- the New Testament, which was printed 51 times (13 times with the Psalms);

- the Bible, printed 18 times.

The popularity of the lectionaries in Slavonic tradition started to decrease from the middle of the $14^{\text {th }}$ (- beginning of the $\left.15^{\text {th }}\right)^{56}$ century ${ }^{57}$. The invention of the printing press did not change this tendency, but resulted in removing the lectionaries, almost entirely, from the Cyrillic printing tradition. The result of this was that in the $19^{\text {th }}$ century only archeographs remembered about the lection$\operatorname{aries}^{58}$.

do tradycji rękopiśmiennej, Materiały z sesji Kraków 7-10 XI 1991, ed. J. RuseK, W. WitкowsKi, A. Naumow, Kraków 1993, p. 167-179).

${ }^{52}$ Cf. А.А. АлексеЕв, Текстология славянской Библии [BSPK.SF 24], Санкт-Петербург 1999, p. 172; Евангелие от Иоанна..., p. 13 (1 ${ }^{\text {st }}$ pagination); J. Osтарсzuк, op. cit., p. 124-125.

${ }^{53}$ Till the half of the $16^{\text {th }} \mathrm{c}$. tetraevangelia were printed on South Slavic territories. The first time the tetraevangelion was printed in Moscow was in the ' 50 s of the $16^{\text {th }} \mathrm{c}$.

${ }^{54}$ For the preliminary list of the early printed tetraevangelia see J. Ostapczuk, Sobotnie i niedzielne perykopy liturgiczne z Ewangelii Mateusza w cerkiewnosłowiańskich lekcjonarzach krótkich, Warszawa 2013, p. 137-148.

${ }^{55}$ For the preliminary list of the Cyrillic early printed New Testaments (also with Psalms) see J. OstapCZuK, op. cit., p. 148-152.

${ }^{56}$ Sometimes it is dated even to the end of the $13^{\text {th }}$ c. (С.Ю. Темчин, Исследования по кирилломефодиевистике..., p. 76.141.

${ }^{57}$ The proportion of Gospel manuscripts dated to the $11^{\text {th }}-13^{\text {th }} \mathrm{c}$. is the following: 29 tetraevangelia - 73 lectionaries. The proportion of the Gospel manuscripts' (dated to the $11^{\text {th }}-14^{\text {th }} \mathrm{c}$.) list prepared by L.P. Zhukovskaia is the following: 250 tetraevangelia -250 lectionaries. The proportion for the Gospel manuscripts dated to the $15^{\text {th }} \mathrm{s}$. is the following: 280 tetraevangelia -110 lectionaries. See Евангелие от Иоанна..., p. 17 ( $1^{\text {st }}$ pagination); А.А. АлексеЕв, ор. сit., p. 22).

${ }^{58}$ Евангелие от Иоанна..., p. 18 (1 $1^{\text {st }}$ pagination). 
It is proved by Cyrillic early printed aprakoses. During the period of almost 300 years they were printed only four times ${ }^{59}$.

Three out of the four aprakoses are the Apostolos-Gospel Sunday lectionaries. All of them were printed on the territories of contemporary West Ukraine (Uherce 1620 , Lutsk $1640^{60}$ and Lviv 1706). The first two aprakoses were printed in a small and movable printing house of Paul Domzhiv Lutkovich Telica ${ }^{61}$.

The last, fourth, aprakos is a full Gospel lectionary. It was printed in Kiev in 1707. This unique example of an early printed full Gospel lectionary was prepared under the instruction of Ivan Mazepa according to the manuscript of the Gospel brought by archimandrite from the Holy Mount Athos ${ }^{62}$. This is why this aprakos is not of East Slavonic origin.

The Cyrillic printing tradition exploited only two types of lectionaries (le and lsk), out of all five confirmed in the Slavonic manuscript tradition (le, lesk, lsk, $l \mathrm{k}$ i lek). It is worth remembering that the early printed Sunday lectionaries were published and most likely used only on a local scale ${ }^{63}$ (in western Ukraine). The model for the only full lectionary came from the holy Mount Athos (possibly from the Zograf Monastery). These themselves are witnesses to an old Slavonic liturgical Gospel tradition that existed in a particular point in time.

The special popularity of the tetragospels and the tendency to standardize the liturgical tradition are the reason for the absence of lectionaries, albeit with four exceptions $s^{64}$, among the early printed Cyrillic books.

Apart from the above-mentioned books containing the text of the Gospel, and at times other parts of the Holy Scriptures, the Cyrillic printing tradition includes also other books ${ }^{65}$ :

\footnotetext{
${ }^{59}$ Seе А.А. Алексевв, Библия в богослужении..., p. 140-141.

${ }^{60}$ For more about this Apostolos-Gospel Sunday lectionary see J. Ostapczuk, Cyrylicki apostot-ewangeliarz niedzielny z Drukarni Brackiej w Łucku (1640 r.), RTeo LVII.2, 2015, p. 169-201.

${ }^{61}$ After the death of Paul Domzhiv Lutkovich Telica, the Brotherhood in Lutsk inherited his printing house (J. OstapCZuK, op. cit., p. 176).

${ }^{62}$ More about this lectionary J. Osтарсzuк, „Та книга Новаго Завета от святыя горы Афонския в дар принесенная...": о единственным старопечатном полном Евангелии-апракос (1707), [in:] Абон и славянский мир. Сборник 3 (Материаль международной научной конференичии, посвященной 1000-летию присутствия русских на Святой Горе. Киев, 21-23 мая 2015 г.), Святая Гора Афон 2016, р. 299-310.

${ }^{63} \mathrm{~A}$.V. Voznesensky suggests that they could not have been printed or used in Moscow (A.B. BозHEСенский, К истории славянской печатной Псалитри, Московская традиция XVI-XVII веков, Простая Псалтирь. Москва-Санкт-Петербург 2010, p. 37, footnote 164).

${ }^{64}$ In the $19^{\text {th }}$ c., lectionaries were printed several times. In all cases, except one, these books were Apostolos-Gospel Sunday lectionaries. They were printed in Lviv and Vienna. See more in: J. OsTAPCZUK, Sobotnie i niedzielne perykopy..., p. 164-166. In the $19^{\text {th }} \mathrm{c}$. the full Gospel lectionary was printed once - in Moscow in 1854. The manuscript model for this aprakos was prepared by Xristaki Pavlovich from Macedonian Dupnitsa (J. Ostapczuk, Cyrylicki apostot-ewangeliarz..., p. 172).

${ }^{65}$ See J. Ostapczuk, Sobotnie i niedzielne perykopy..., p. 154-155.
} 
- the Gospel readings for Holy Thursday and Good Friday of the Holy Week, printed 18 times;

- the Gospel readings for all days of the Holy Week, printed 3 times;

- the Gospel readings for Sunday Orthros (Matins), printed once.

All these books do not exceed 50 pages.

The last three types of the Gospel books have sprung, most likely, on the basis of liturgical practice and seems to be the result of a practical attitude to reading several fragments from the Holy Scripture during one service ${ }^{66}$. These books provide some compound Gospel pericopes for those days with special significance in the one of liturgical cycle - the Holy Week. As it was mentioned at the beginning, the pericope for the Good Friday Vespers comprises of five fragments. Should a priest use the tetraevangelion, he has to look for every fragment at its different parts, but if he uses the above-mentioned books, he can simply read the compound pericopes arranged in the appropriate sequence. This makes the celebration easier, especially in the case of the quite complicated and long services of the Holy Week.

This short comparison of different types of the manuscripts and early printed books of the Gospel text in Slavonic cannot be treated as complete and exhaustive ${ }^{67}$. Remarkable variations of details presented in this publication are fundamental for Bible studies and Slavonic Gospel scholarship in general. These were confronted and presented together in order to make it easily accessable to all students of the subject, and then there who will no longer need to explore many other scientific publications (including catalogues) devoted to the Slavonic tradition. This comparison makes it possible to show what types of the Gospel were transmitted into Slavonic ground from the Greek tradition (tetraevangelion and different types of the lectionaries) as well as which were originally created by the Slavs (the Lenten tetraevangelion and the Easter-Sunday lectionary).

\section{Bibliography}

Aland K., Kurzgefasste liste der griechischen Handschriften des Neuen Testaments: I Gesamtübersicht (Arbeiten zur Neutestamentlichen Textforschung 1), Berlin 1963.

Aland K., Aland B., The Text of the New Testament. An Introduction to the Critical Editions and to the Theory and Practice of Modern Textual Criticism. Second Edition, Translated by E.F. RHODES, Grand Rapids Michigan 1989.

${ }^{66}$ Gospel pericopes for Thursday and Friday of the Great and Holy Week were sometimes attached to the early printed tetraevangelia. As examples can serve books printed in: Lviv at 1743 and in Moscow at $1771,1774,1779,1785,1789$ etc.

${ }^{67}$ Information about some early printed Cyrillic books with readings for the Great and Holy Week is derived from catalogues. A detailed typological classification needs the examination de visu of these editions. 
Dolezal M.L., The Elusive Quest for the „Real Thing”: The Chicago Lectionary Project Thirty Years On, Ges 35/2, 1996, p. 128-141.

The Epistle Lectionary. The Apostolos of the Greek Orthodox Church According to the King James Version. Emended and Arranged for the Liturgical Year, Etna (California) 2004.

GaRzaniti M., Die altslavische Version der Evangelien: Forschungsgeschichte und zeitgenössische Forschung [BSPK.SF 33], Köln-Weimar-Wien 2001.

KASZlej A., Wpływ cerkiewnosłowiańskiej książki drukowanej na rękopiśmienna (na podstawie zbiorów Biblioteki Narodowej w Warszawie), [in:] Najstarsze druki cerkiewnosłowiańskie i ich stosunek do tradycji rękopiśmiennej, Materiały z sesji Kraków 7-10 XI 1991, ed. J. Rusek, W. Witkowski, A. Naumow, Kraków 1993, p. 167-179.

Moszyński L., Zografskie i Mariańskie Tetraewangelia jako księgi liturgiczne. Część I: Etap głagolski, ПК XIV-XV, 1985, p. 76-99.

Ostapczuk J., Cerkiewnosłowiański przekład liturgicznych perykop okresu Paschalnego i święta Pięćdziesiątnicy w rękopiśmiennych ewangeliarzach krótkich, Warszawa 2010.

Ostapczuk J., Cyrylicki apostol-ewangeliarz niedzielny z Drukarni Brackiej w Łucku (1640 r.), RTeo LVII.2, 2015, p. 169-201.

Ostapczuk J., Sobotnie i niedzielne perykopy liturgiczne z Ewangelii Mateusza w cerkiewnosłowiańskich lekcjonarzach krótkich, Warszawa 2013.

Ostapczuк J., „Та книга Новаго Завета от святыя горы Афонския в дар принесенная...”: о единственным старопечатном полном Евангелии-апракос (1707), [in:] Афон и славянский мир. Сборник 3 (Материалы международной научной конференции, посвященной 1000-летию присутствия русских на Святой Горе. Киев, 21-23 мая 2015 г.), Святая Гора Афон 2016, p. 299-310.

Schenk W., Die gnostisierende Deutung des Todes Jesu und ihre kritische Interpretation durch den Evangelisten Markus, [in:] Gnosis und Neues Testament: Studien aus Religionswissenschaft und Theologie, ed. K.-W. TröGER, Berlin 1973, p. 231-243.

VRANA J., O tipovima, redakcijama i medusobnom odnosu staroslovjenskih evanđelija (Četveroevandelja), Sla XXIX.4, 1960, p. 552-571.

Wikgren A., Chicago studies in the Greek Lectionary of the New Testament, [in:] Biblical and Patristic Studies in Memory of Robert Pierce Casey, ed. J.N. Birdsall, R.W. Thomson, Freiburg 1963, p. $96-121$.

Алексевв А.А., Библия в богослужении. Византийско-славянский текиионарий, Санкт-Петербург 2008.

Алексевв А.А., Византийско-славянский профитологий (формирование состава), ТОДЛ, LVI, 2004, p. 46-77.

Алексевв А.А., Текстология славянской Библии [BSPK.SF 24], Санкт-Петербург 1999.

Вознесенский А.В., К истории славянской печатной Псалитри, Московская традиция XVIXVII веков. Простая Псалтирь, Москва-Санкт-Петербург 2010.

Евангелие от Иоанна в славянской традиции [NTP I], ed. А.А. АЛЕКсеЕв, А.А. ПичхаДЗЕ, М.Б. БАБИцКАЯ et al., Санкт-Петербург 1998. 
Пентковский А.М., Лекиионарии и четвероевангелия в византийской и славянской титургических традициях (Приложение 1), [in:] Евангелие от Иоанна в славянской традиции [NTP I], ed. А.А. АлЕКСеЕв, А.А. ПичХАДЗЕ, М.Б. БАБИЦКАЯ et al., Санкт-Петербург 1998, p. 3-54.

Сводный каталог славяно-русских рукописных книг, хранящихся в России, странах СНГ и Балтии, XIV век, fasc. 1 (Апокалипсис - Летопись Лаврентьевская), еd. О.А. КнязевскАя, Н.А. КоБяк, А.Л. Лифшиц, Н.Б. ТихомиРов, А.А. Турилов, Н.Б. ШеЛАмАновА, Москва 2002.

Темчин С.Ю., Сербский столпный апракос Равулы (ок. 1353 г.): происхождение, особенности языка, структура, SVi 52.2, 2003, p. 131-177.

Темчин С.Ю., О возможном балканском влиянии на структуру церковнославянских богослужебных книг ВКЛ и Польского Королества, SRu XVIII, Budapest 2000, p. 275-280.

ТЕмчин С.Ю., Исследования по кирилло-мефодиевистике и палеославистике [KWSS 5], Kraków 2010.

Темчин С.Ю., Столпный апракос - еще один неизвестный структурный тип славянского служебного Евангелия (по рукописям XIII-XVI веков), [in:] Библия в духовной жизни, истории и культуре России и православного славянского мира: К 500-летию Геннадиевской Библии, Сборник материалов международной конференции (Москва, 21-26 сентября 1999 г.), еd. Г. БАРАНКОВА, Москва 2001, р. 127-159.

Темчин С.Ю., Пасхально-воскресный апракос - неизвестный структурный тип славянского служебного Евангелия, УЗРПУ, t. 4, Москва 1998, p. 61-79.

Турилов А.А., Л.В. МошковА, Славянские рукописи Абонских обителей, Фессалоники 1999.

Abstract. The paper presents the rules for typological classification of Slavonic manuscripts and early printed books with the Gospel text. It enumerates different types of the books with the Gospel and sometimes also with other parts of the Holy Scripture. Information about the Greek tradition of the Gospel is also included in the article and serves as the basis of comparison.

Keywords: typological classification, Cyrillic, manuscript, early printed books, Gospel.

Jerzy Ostapczuk

The Christian Theological Academy

ul. Miodowa 21c

00-246 Warszawa, Polska/Poland jostap@wp.pl 